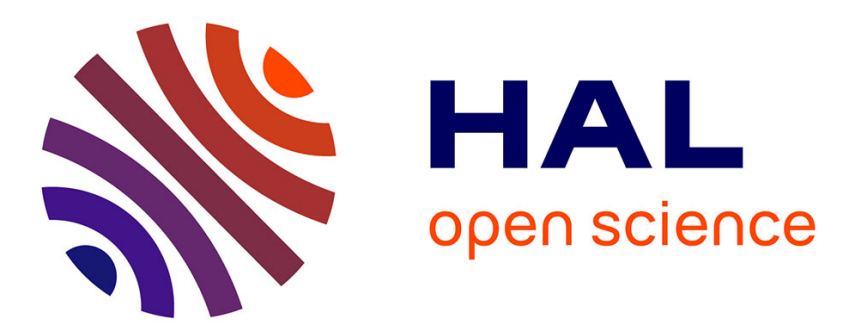

\title{
Social Innovation on the Rise: yet another buzzword in time of austerity?
}

Francesco Grisolia, Emanuele Ferragina

\section{To cite this version:}

Francesco Grisolia, Emanuele Ferragina. Social Innovation on the Rise: yet another buzzword in time of austerity?. Salute e società, 2015, 2015-1 EN, pp.71-84. halshs-01512107

\section{HAL Id: halshs-01512107 https://shs.hal.science/halshs-01512107}

Submitted on 21 Apr 2017

HAL is a multi-disciplinary open access archive for the deposit and dissemination of scientific research documents, whether they are published or not. The documents may come from teaching and research institutions in France or abroad, or from public or private research centers.
L'archive ouverte pluridisciplinaire HAL, est destinée au dépôt et à la diffusion de documents scientifiques de niveau recherche, publiés ou non, émanant des établissements d'enseignement et de recherche français ou étrangers, des laboratoires publics ou privés. 


\title{
Social Innovation on the Rise: yet another buzzword in time of austerity $^{1}$ ?
}

Francesco Grisolia $^{2}$ and Emanuele Ferragina ${ }^{3}$

\begin{abstract}
We challenge the idea that social innovation can constitute an effective strategy to counterbalance the retrenchment of public social provisions. The changes within the Italian healthcare system, one of the most important sectors of the welfare state, in which social innovation ideas have been widely discussed, are a clear example of a broader trend toward decentralisation and marketization. In conjunction with a new balance between public and private funding, these changes are contributing to increased inequalities and territorial disparities. A social innovation perspective, which is not embedded within a structural reform of the Italian welfare state and the health care system, might simply become a convenient buzzword to forward neoliberal ideology in a time of austerity.
\end{abstract}

\section{Introduction}

Over the last two decades social innovation has gained significant popularity ${ }^{4}$ as a strategy to tackle new social risks (Bonoli, 2005; Taylor- Gooby, 2004) including population ageing and its health correlates (Franz, Hochgerner and Howaldt, 2012; Hubert, 2010; Mulgan et al., 2007, 2010; Murray, Caulier-Grice and Mulgan, 2010; OECD, 2011; Phills et al., 2009). However, as other concepts recently developed within the academic debate - among them, social capital (Ferragina, 2012, 2013a; Ferragina and Arrigoni, 2014; Muntaner, Lynch and Davey Smith, 2001) - social innovation might soon turn out to be simply another way to juxtapose the qualifier "social" to the private sector jargon (Phills, Deigleimer and Miller, 2008, p. 36), in order to avoid heated discussions on structural inequalities ${ }^{5}$.

Social innovation is commonly defined as new ideas (products, services and models) that simultaneously meet social needs and create new social relationships or collaborations. These innovations are considered both good for society and capable of enacting greater societal involvement in the provision of social services (Murray, Caulier-Griece and Mulgan, 2010, p.3) ${ }^{6}$. The Young Foundation, in order to distinguish between social and business innovation, stressed that social innovation is developed and diffused via organisations, whose primary purposes are not centred on mere profit maximisation (Mulgan et al., 2007, p. 8). The Bureau of European Policy Advisers more precisely defined social innovation as socially oriented in both ends and

\footnotetext{
1 This paper is part of the research project, Social capital, health and health care system in Calabria, co-financed by the European Social Fund (European Commission) and the Calabria Regional Administration. We are thankful to the Calabria Regional Administration for its financial support of Francesco Grisolia's post-doctoral fellowship.

2 Postdoctoral Fellow, Magna Graecia University of Catanzaro. grisolia@unicz.it.

3 Lecturer University of Oxford, Oxford Institute of Social Policy.

emanuele.ferragine@sciencespo.fr

4 As shown by Google trend, compared to February 2004 (value: 48), the online searches of the term social innovation picked in October 2013 (99) and April 2014 (100):

https://www.google.it/trends/explore\#geo\&q=social+innovation. Narrowing the search option to Italy, a sharp increase emerges between June 2011 and June 2014:

https://www.google.it/trends/explore\#q=social+innovation\&geo=IT.

5 As Pol and Ville (2009) show, some scholars consider social innovation a 'passing fad', while others find the concept valuable as it identifies a distinct and potentially crucial type of innovation.

6 One of the main innovations in the health care sector is the so-called e-health. For a discussion, see Eysenbach (2000), and Cipolla and Maturo (2014).
} 
means (Hubert, 2010). According to these influential definitions, social innovation is characterised by: the capacity to address social needs that traditional policy seems increasingly unable to tackle; the empowerment of groups and individuals; and the willingness to change social relations. Hence, social innovation is often presented as a way to increase the quality of social services and their cost-effectiveness, offering equivalent, if not superior, outcomes despite considerable budget constraints.

The aim of this paper is to question the idea that social innovation can substantially address the deficiencies and inadequacies of the welfare state. In particular, discussing the case of the Italian health care system, we show that social innovation cannot counter-balance increasing cuts in social spending. The paper has two sections. The first sketches the political climate and context surrounding the Italian national and regional healthcare systems, in which the concept of social innovation rose as a fundamental element to support welfare reforms. The second analyses the changes within the Italian healthcare system as part of a wider trend of reforms in Europe that are contributing to increasing inequalities. We conclude by suggesting that a social innovation perspective, which is not embedded within a structural reform of the Italian welfare state and the health care system, might simply become a convenient buzzword, useful for advancing neoliberal ideology in a time of austerity, ${ }^{7}$ rather than a tool for addressing the vital social challenges we are facing today.

\section{The context}

The effectiveness, flexibility and economic sustainability of welfare states have been under severe scrutiny since the 1970s. More recently, the emergence of the welfare $\operatorname{mix}^{8}$ debate has primarily focused on the necessity to decrease state funding for social services while meeting, at the same time, rapidly growing welfare demands ${ }^{9}$. This debate clearly overlaps with the spread of social innovation idea within policy-making and academia. In particular, there are two areas of convergence. First, the emphasis on individual and group empowerment is compatible with the reduction of public social spending, and consequently with the shift from "public to private social responsibility" (Gilbert, 2002). Secondly, social innovation is often presented by its advocates as a strategy to tackle pressing social needs more effectively and efficiently by "mobilising people's creativity" and making "better use of scarce resources" (Hubert, 2010, p. 7) than both the state and the market (Murray, Caulier-Grice and Mulgan, 2010, p. 3).

The concept of social innovation emerged ${ }^{10}$ during the 1990 s in a political and economic context characterised by the end of Fordism and the attempt of neoliberalism to actively promote the reduction of public involvement. The diversification of suppliers - involving liberalisation and out-sourcing of production - and the devolution of authority from central to local governments have been among the major trends across countries, thereby reshaping social services (Martinelli, 2012, p. 170). In Italy, the process was characterised by: a generalised aversion to public intervention, the representation of the welfare state as an obstacle to economic growth and the reframing of welfare in terms of residual policies (Pennacchi, 2008, p. 3-5).

Many scholars have considered the restructuring of the Italian welfare state - characterised by devolution to local authorities and diversification of suppliers (through vertical and horizontal subsidiarity) - as innovative by default; hence, inherently better than previous arrangements. Much empirical evidence shows, however, that this is not the case and that, on the contrary, strong exclusionary processes have accompanied these reforms (Martinelli, 2012, p. 175), diminishing the universality of the Italian health care system. Maino and Ferrera (2013, p. 323)

\footnotetext{
${ }^{7}$ For a description of neoliberal ideology and its multiple manifestations, see Gamble (2009) and Harvey (2005).

${ }^{8}$ On the welfare mix debate see Ascoli and Ranci (2002).

${ }^{9}$ In addition, the corruption scandals alimented the need for greater transparency in the economic relations between local authorities and private suppliers (Ascoli, Pavolini and Ranci, 2002, p. 142-143).

${ }^{10}$ Hubert (2010, p. 31) suggested that social innovation is rooted in the work of the founding fathers of sociology (i.e. Weber and Durkheim) and in the influential definition of innovation proposed by Schumpeter. In this regard, see also Moulaert (2009) and Moulaert et al. (2013).
} 
have clearly pointed out the danger of a missed integration between the traditional, so-called 'first' welfare state (mostly publicly provided) and the emerging 'second welfare' (mostly private or community based). This missed integration is contributing to further reductions in the capacity of the welfare state to recalibrate its structure and, as a consequence, inequalities and territorial disparities (already in place) are rapidly increasing.

Italy is characterised by a 'peculiar' combination of profound territorial and socioeconomic divides $^{11}$, on-going decentralization policies, declining state investments, and budget cuts (especially at the regional level) due to debt restructuring plans (the so-called "piani di rientro regionali"). However, education, health assistance and care services are the basis of social citizenship (Marshall, 1950), and for this reason, a reduction of public spending in these areas can fundamentally undermine universal access (Martinelli, 2012). In this context of protracted austerity, the decentralisation of the Italian National Healthcare System (NHS) has contributed to widening territorial inequalities and reducing access to services. It has been highlighted that in order to avoid a zero-sum game, in which the eventual gains of the more efficient regions are mirrored by the losses in performance of the weaker areas, a renewed active role of the state in terms of spending and monitoring is urgently required (Pavolini and Vicarelli, 2012, p. 484485). Instead, budget constraints have become a dominant concern, overshadowing the promotion and safeguard of public access to health care (Dirindin and Vineis, 2004, p. 214-215).

\section{Discussion}

Recent reports on the state of the Italian NHS (CEIS, 2013; OASI, 2013; Osservasalute, 2013) show, on the one hand, signs of economic recovery and budget rebalancing and, on the other hand, widening territorial inequalities. In Italy the NHS is less costly than in Britain, France and Germany, with less per capita spending and a smaller spending increase over the last decade (Cantù and Longo, 2013, p. 1). ${ }^{12}$ Although, the Italian NHS deficit has been reduced and its financial sustainability in the medium term is not at risk, the EU Fiscal Compact imperatives have been translated into a state therapy of indiscriminate cuts, the so called "tagli lineari" ("linear cuts") (Cantù and Longo, 2013, p. 2). Hence, the real threat to the sustainability of the NHS, especially from the point of view of curtailing universal access, does not seem to arise from the overall deficit, but rather from the lack of investment in technology and infrastructure. More specifically, regional budgets have been rebalanced mainly by reducing the inputs, while neglecting outputs and service outcomes. ${ }^{13}$ There is a lack of investment both at the national and local level, which is especially pronounced in the most deprived regions. While the 2003-2010 average per capita investment spending was 59 Euros - the peaks were registered in EmiliaRomagna (111) and in the autonomous province of Trento (105) - the expenditure in the southern regions was systematically below the national average, reaching the lowest levels in Calabria (20) and Apulia (29) (Cantù and Longo, 2013, p. 3). The prevailing focus on inputs reduction has translated into hiring and wage freezes ${ }^{14}$ (especially in the regions subject to debt restructuring plans), a strategy that is likely to consolidate shortages and deficiencies in already inefficient regional systems.

\footnotetext{
${ }^{11}$ For a discussion of different models of welfare state and healthcare systems, see Bertin (2012). For an overview on health and social inequalities see Costa, Cislaghi and Caranci (2009), and Niero and Bertin (2011).

${ }^{12}$ The Osservasalute 2013 report confirms such condition. The total amount of public spending declined between 2009 and 2010 (from 103 to 101 billion euros), with a deepening trend between 2011 and 2012. http://www.salute.gov.it/imgs/C_17_notizie_1551_listaFile_itemName_0_file.pdf.

${ }^{13}$ While the term output indicates the result of a specific healthcare provision (as performing an electrocardiogram), outcome represents the changes in individual, group or population health deriving from one or more interventions planned at various levels (a single surgical intervention, a service of instrumental diagnostics or a vaccination plan). Health outcomes may also stem from non-sanitary interventions, as the opening of a factory and its polluting effects on a certain area or, conversely, the construction of sports facilities in the same site, constituting a potential incentive to undertake physical activity.

${ }^{14}$ The number of employees within public hospitals has significantly declined since 2010 (Rapporto Osservasalute 2013: 2). http://www.salute.gov.it/imgs/C_17_notizie_1551_listaFile_itemName_0_file.pdf.
} 
In addition, declining public investment is not proportionally compensated by an increase in the out-of-pocket spending, which seems to be more influenced by personal income. The presumed inverse proportionality between private expenditure and public healthcare performance is not confirmed by empirical evidence in Italy: southern regions, characterised by lower levels of efficiency, also show the lowest levels of private spending in the country 15 . This might suggest that tight expenditure constraints and increased prescription charges are instigating an alarming tendency toward under-treatment and widening inequalities between the worse and the better off regions (Cantù and Longo, 2013, p. 4). As shown by two subsequent Ministry of Health reports on the fulfilment of LEA ("Livelli Essenziali di Assistenza", the scores of health care adequacy)16, there is a correlation between tight budget constraints and deteriorating quality standards (Ministero della Salute, 2013, p. 20; 2014, p. 22-23;). In 2011 and 2012, nearly all the regions subject to debt restructuring plans - Abruzzo, Molise, Apulia, Campania, Calabria and Sicily - have not been compliant, or just partially so, with basic healthcare provisions. This situation appears even more problematic if we consider how the economic crisis has not only reduced private spending, but also diminished the mobility of NHS users among regions 17. Finally, there is a strong correlation between the regional poverty index and the inability of the regional healthcare systems to comply with the provision of basic services (measured through the LEA, see Table 1 and Graph. 1).

\footnotetext{
${ }^{15}$ Out-of-pocket spending for prescription charges and drugs (although not inversely proportional to the shrinking of public investment) has more than doubled between 2003 (11,3 bln euro, 5,3\% of GDP) and $2012(23,7$ bln, 12,2 \%) (Rapporto Osservasalute 2013, http://www.salute.gov.it/imgs/C_17_notizie_1551_listaFile_itemName_0_file.pdf).

${ }^{16}$ The acronym LEA (Basic Healthcare Provision) denotes the essential health services

- free or with a prescription charge - which any citizen is entitled to receive from the NHS. The uniform supply of LEA in every Italian region was initially regulated by the Ministerial Decree (DM) 12 December 2001, in accordance with the Legislative Decree (D.Lgs.) 56/2000, defining a set of indicators to assess the quality of healthcare. The Ministerial Decree was subsequently replaced by the Prime Minister Decree of 23rd of April 2008. Current LEA includes 5700 prevention, care and rehabilitation services and provisions. The regional healthcare compliance with the parameters defined by the Ministry of Health is under the supervision of the LEA Committee. http://www.salute.gov.it/portale/ministro/p4_5_2_4_1.jsp?lingua=italiano\&menu=uffCentrali\&label=uffCentrali\&id=1 151.

${ }^{17}$ Whose social cost is entirely sustained by the patients and their families.
} 


\section{TABLES AND GRAPHS}

Table 1 Poverty Index and Scores Health Care Adequacy

\begin{tabular}{lcc}
\hline & Poverty Index & $\begin{array}{c}\text { Scores Health Care } \\
\text { Adequacy (LEA) }\end{array}$ \\
\hline Italian Average & 12.7 & \\
Piedmont & 7.3 & 186 \\
Lombardy & 6 & 184 \\
Veneto & 5.8 & 193 \\
Liguria & 8.1 & 176 \\
Emilia Romagna & 5.1 & 210 \\
Northern Regions & 6.2 & \\
Tuscany & 6.8 & 193 \\
Umbria & 11 & 171 \\
Marche & 8.6 & 165 \\
Lazio & 6.3 & 167 \\
Central Regions & 7.1 & \\
Abruzzo & 16.5 & 145 \\
Molise & 20.5 & 146 \\
Campania & 25.8 & 117 \\
Apulia & 28.2 & 160 \\
Basilicata & 24.5 & 133 \\
Calabria & 27.4 & 157 \\
Sicily & 29.6 & \\
Southern Regions & 26.2 & \\
R2 & 0.639 & \\
\hline
\end{tabular}

Graph. 1 Correlation Poverty Index and Scores Health Care Adequacy (LEA)

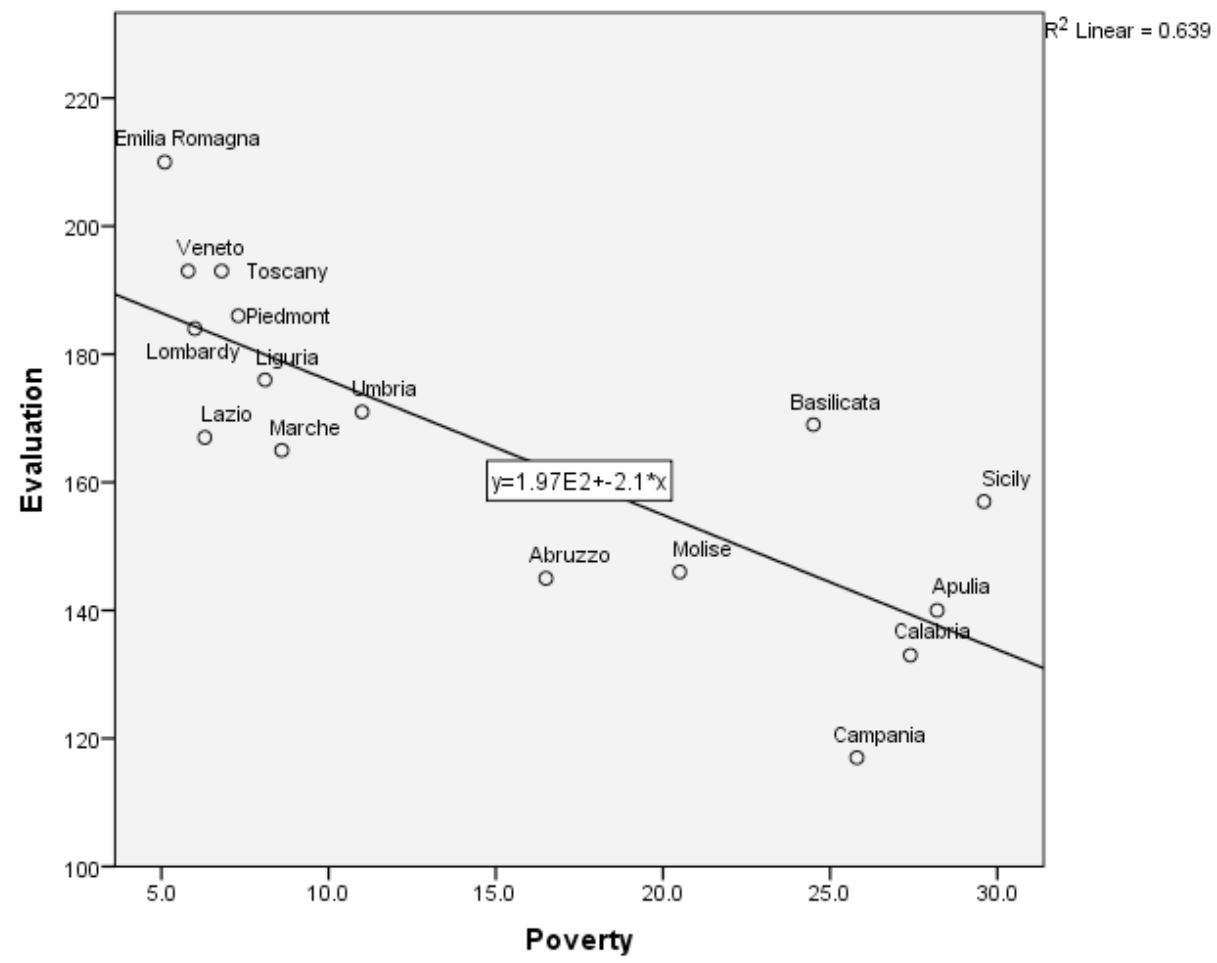

Source: ISTAT, "Net family income distribution indicators" (http://dati.istat.it/index.aspx?queryid=4836), and Ministero della Salute, Direzione Generale Programmazione Sanitaria (2014, p. 22-23). 
In this context of 'neoliberal austerity', a strong call in favour of social innovation might hide the attempt to shift public attention from structural deficiencies and disparities to individual and group responsibility, following the vision: "doing more with less" ${ }^{18}$. In order to guarantee universal coverage and universal social rights, however, the health care system cannot be managed with the logic of mere cost-effectiveness alone. A healthy population is the precondition for any well-functioning economy, not the other way around. As such, the enhancement of "politically motivated policies under the pretence of budget cuts" can be particularly dangerous in its consequences for population health (Kleinert and Horton, 2013, p. 1074).

The current economic difficulties, epidemiological changes and the foreseeable impact of population ageing suggest the need for substantial investments and structural transformations of the health care system - for instance, the regeneration and upgrading of the existing facilities. The idea of implementing innovative procedures and services without any intervention within healthcare infrastructures seems, at best, quite optimistic (Cantù and Longo, 2013, p. 3). As noted by Caritas, an important charitable organization ${ }^{19}$, economic unease and social exclusion in Italy have been exacerbated by the on-going austerity policies. Such measures have weakened key sectors of the welfare state during a period of economic distress that demanded stronger social protection. Therefore, the promotion of 'innovative forms of solidarity' at the community level is simply not enough. Instead, a strengthening of institutional responsibilities to society's weakest members stands essential in combating new forms of poverty and social exclusion (Nanni, 2014). To conclude, we do not consider social innovation per se able to substantially tackle pressing social needs. Rather, the all-innovating and self-empowering jargon currently in vogue might disguise a dangerous inattention to structural inequalities, adversely affecting health outcomes across the board, but especially of the poorest. Among the therapies prescribed by the neoliberal orthodoxy - liberalisation, deregulation, devolution, individual or group empowerment - social innovation might soon reveal itself as a convenient buzzword, an eclectic concept to dissimulate political choices, legitimated by the doctrine of budgetary constraints. In our view, the redistribution of resources "from past to present generations" - keeping constant the overall public spending - and the shift from a "transfer-based" to a "service-based" welfare state (for a discussion, see Ferragina, 2013b) would represent a truly innovative approach to Italian social policy, offering a credible and responsible alternative to the magic wand of social innovation.

\footnotetext{
18 See "Welcome to the Project on Social Innovation: Doing More with Less" (http://www.socialinnovation.ash.harvard.edu/welcome-to-innovation-cities-2.html). Welcome to the Project on Social Innovation is an online hub launched in 2011 by the Ash Centre for Democratic Governance and Innovation at the Harvard Kennedy School of Government.

${ }^{19}$ Caritas is the pastoral branch of the Italian Episcopal Conference (CEI). According to its statute, CEI promotes the value of charity to contribute to "the integral development of man, to social justice and peace, with a particular attention for the destitute" (http://www.caritasitaliana.it/home_page/chi_siamo/00003684_Statuto.html).
} 


\section{BIBLIOGRAPHY}

Ascoli U., Ranci C., (eds.) (2002). Dilemmas of the Welfare Mix. The New Structure of Welfare in an Era of Privatization. New York: Springer.

Ascoli U., Pavolini E., Ranci C. (2002). "The New Partnership: The Changing Relationship between State and the Third Sector in the Scenario of New Social Policies in Italy". In: Ascoli U., Ranci C. (eds.), Dilemmas of the Welfare Mix. The New Structure of Welfare in an Era of Privatization. New York: Springer.

Bertin G. (2012). "Modelli di welfare e sistemi sanitari: quali omogeneità e specificità". Salute e Società, 1: 33-64. DOI: 10.3280/SES2012-001003.

Bonoli G. (2005). "The Politics of the New Social Policies. Providing Coverage Against New Social Risks in Mature Welfare States". Policy and Politics, 33: 431-450.

DOI: $10.1332 / 0305573054325765$.

Bosi P. (2008). "L'irresistibile attrazione dei trasferimenti monetary". In: Guerzoni L. (ed.), La riforma del welfare. Dieci anni dopo la "Commissione Onofri".

http://www.astrid-online.it/static/upload/protected/BOSI/BOSI-trasferimentimonetari_def.pdf.

Cantù E., Longo F. (2013). Rapporto OASI 2013. SDA and CERGAS. Bocconi University. http://www.sossanita.it/doc/2014 01 OASI 2013 EXSUM.pdf.

CEIS (2013). IX Rapporto Sanità - Crisi economica e Sanità: come Cambiare le Politiche Pubbliche. Tor Vergata University-Rome.

http://www.creasanita.it/index.php/it/9-rapporto-sanita/34-crisi-economica-e-sanita-comecambiare-le-politiche-pubbliche.

Cipolla C., Maturo A. (ed.) (2014). Sociologia della salute e web society. Milano: Franco Angeli.

Costa G., Cislaghi C., Caranci N. (ed.) (2009). "Le disuguaglianze sociali di salute.

Problemi di definizione e di misura". Salute e Società, 1.

Dirindin N., Vineis P. (2004). In buona salute. Dieci argomenti per difendere la sanità pubblica. Torino, Einaudi

Eysenbach G. (2001). "What is e-health?”. Journal of Medical Internet Research, 3 (2): e20.

Ferragina E. (2012). Social Capital in Europe: a Comparative Regional Analysis.

Cheltenham: Edward Elgar.

Ferragina E. (2013a). "The socio-economic determinants of social capital and the mediating effect of history: Making Democracy Work revisited". International Journal of Comparative Sociology, 54: 48-73. DOI: 10.1177/0020715213481788.

Ferragina E. (2013b). Chi Troppo, Chi Niente. Milano: Rizzoli-BUR.

Ferragina E., Arrigoni A. (2014). The Parabola of Social Capital: Requiem for a Theory?. Presented at the Social Policy Association Conference, Sheffield 14- 16 July 2014.

Franz H., Hochgerner J., Howaldt J. (ed.) (2012). Challenge Social Innovation.

Berlin-Heidelberg: Springer.

Gamble A. (2009). The Spectre at the Feast. London: Palgrave Macmillan.

Gilbert N. (2002). Transformation of the Welfare State. The Silent Surrender of Public Responsibility. Oxford-New York: Oxford University Press.

Harvey D. (2005). A Brief History of Neoliberalism. Oxford: Oxford University Press.

Hubert A. (ed.) (2010). Empowering People, Driving Change: Social Innovation in the European Union. Brussels: BEPA - Bureau of European Policy Advisers.

Kleinert S., Horton R. (2013). "Health in Europe - Successes, Failures, and New Challenges". The Lancet, 381: 1073-1074. DOI: 10.1016/S0140-6736(13)60603-0.

Maino F., Ferrera M. (ed.) (2013). Primo Rapporto sul Secondo Welfare in Italia. Torino: Centro di Ricerca e Documentazione "Luigi Einaudi".

http://www.secondowelfare.it/edt/file/PRIMO_RAPPORTO_SUL_SECONDO_WELFAR E_IN_ITALIA.pdf. 
Marshall T.H. (1950). Citizenship and Social Class: and Other Essays. Cambridge: Cambridge University Press.

Martinelli F. (2012). "Social Innovation or Social Exclusion? Innovating Social Services in the Context of a Retrenching Welfare State". In: Franz H., Hochgerner J., Howaldt J. (ed.), Challenge Social Innovation. Berlin- Heidelberg: Springer.

Ministero della Salute, Direzione Nazionale della Programmazione Sanitaria - Ufficio VI (2013), Adempimento "mantenimento dell'erogazione dei LEA" attraverso gli indicatori della griglia LEA - Metodologia e risultati anno 2011. http://www.salute.gov.it/imgs/C_17_pubblicazioni_2067_allegato.pdf.

Ministero della Salute, Direzione Nazionale della Programmazione Sanitaria. Ufficio VI (2014). Adempimento "mantenimento dell'erogazione dei LEA" attraverso gli indicatori della griglia LEA - Metodologia e risultati anno 2012.

http://www.salute.gov.it/imgs/C_17_pubblicazioni_2154_allegato.pdf.

Moulaert F. (2009). "Social Innovation: Institutionally Embedded, Territorially (Re)produced". In: MacCallum D. et al., (ed.), Social innovation and territorial development. Farnham and Burlington: Ashgate.

Moulaert F., MacCallum D., Mehmood A., Hamdouch A. (2013). The International Handbook of Social Innovation. Collective Action, Social Learning and Transdisciplinary Research. Cheltenham: Edward Elgar.

Mulgan G. (2010). Innovations in Health: Approaches from the Regional Innovation Funds. London: The Young Foundation.

Mulgan G., Tucker S., Rushanara A., Sanders B. (2007). Social Innovation. What it is, why it matters and how it can be accelerated. London: The Young Foundation.

Muntaner C., Lynch J., Davey Smith G. (2001). "Social Capital, Disorganized Communities, and the Third Way: Understanding the Retreat from Structural Inequalities in Epidemiology and Public Health". International Journal of Health Services, 31: 213-37.

Murray R., Caulier-Grice J., Mulgan G. (2010). The Open Book of Social Innovation. London: The Young Foundation and Nesta.

Nanni W. (2014). False Partenze. Rapporto 2014 sulla Povertà e l'Esclusione Sociale in Italia. CARITAS.

http://www.caritasitaliana.it/home_page/area_stampa/00004776_False_partenze__Rappor to Caritas Italiana 2014 su poverta e esclusione sociale in Italia.html.

Niero M., Bertin G. (ed.) (2011). "Vulnerabilità e fragilità sociale. Una teoria delle disuguaglianze di salute". Salute e Società, 3.

OECD (2011). Fostering Innovation to Address Social Challenges. http://www.oecd.org/science/inno/47861327.pdf.

Pavolini E., Vicarelli G. (2002). "Is Decentralization good for your health? Transformations in the Italian NHS". Current Sociology, 60 (4): 472-488.

Pennacchi L. (2008). "Il peso di fattori di tipo strategico-culturali". In: Guerzoni L., (ed.), La riforma del welfare. Dieci anni dopo la "Commissione Onofri".

http://www.astrid-online.it/static/upload/protected/PENN/PENNACCHI-Fattori-strategcult_def.pdf.

Phills J. A., Deigleimer K., Miller D. T. (2008), "Rediscovering Social Innovation", Stanford Social Innovation Review: 34-43.

https://ssir.org/articles/entry/rediscovering_social_innovation.

Pol E., Ville S. (2009). "Social Innovation: Buzz word or enduring term?". The Journal of SocioEconomics, 38(6): 878-885.

Ricciardi W., Solipaca A. (ed.) (2013). Rapporto Osservasalute 2013. National Observatory on Health in the Italian Regions - Catholic University of Rome.

Taylor-Gooby P. (2004). "New risks and social change". In: Taylor-Gooby P. (ed.), New risks, new welfare? Oxford: Oxford University Press. 